\title{
THE FIRST PERIODICALS \\ OF BOSNIA AND HERZEGOVINA ${ }^{1}$
}

\begin{abstract}
:
In 1865 a printing house was opened in Sarayevo and the publication of the first newspapers began in the Bosnia Vilayet. The article deals with periodicals published in Bosnia and Herzegovina from 1866 to 1878: Bosanski vjestnik, Bosna, Sarajevski cvjetnik, Neretva.
\end{abstract}

\section{Keywords:}

The Bosnian Vilayet, the printing house, Ignaty Sopron, Mehmed Shachir Kurtchehaich, first periodicals.

Аннотация: К.В. МельчаковА. «Первые ПериОдические иЗдания Боснии и Герцеговины».

В 1865 г. в Сараево открылась типография и начался выпуск первых газет в Боснийском вилайете. В статье идёт речь о периодических изданиях, которые выходили в Боснии и Герцеговине с 1866 по 1878 гг. («Боснийский вестник», «Босния», «Сараевский цветник», «Неретва»).

\section{Ключевые слова:}

Боснийский вилайет, типография, Игнатий Сопрон, Мехмед Шачир Куртчехаич, «Боснийский вестник», «Босния», «Сараевский цветник», «Неретва».

Tn 1865 a new administrative unit, the Bosnian Vilayet, appeared on the map of the Ottoman Empire. During the course of the Tanzimat reforms (plural of the Arabic word "Tanzim," meaning streamlining), the Bosnian Pashalyk and the Herzegovina Sanjak were combined. From the Ottoman Porte came instructions to establish a printing house in the Bosnian lands and to begin printing the first newspapers in the history of the region.

These events were closely connected with the name of the reformer Topal Sherif Osman Pasha (1804-74), one of the most advanced people of his time and the former Governor General of the Bosnian Vilayet in 1861-69.

To set up the printing house, the Ottoman authorities invited the publisher Ignaz Karl Sopron (1821-97) to Sarayevo from the Austrian city of Zemun (now in Belgrade), who himself delivered all the necessary equipment, sets of letters with the Cyrillic, Latin and Greek alphabets. A three-year contract was concluded with Sopron: he was provided with free premises, 38,000 guldens of annual payment for production expenses and a salary of 2000 guldens. Later, the typesetter Kadri-effendi arrived from Constantinople, bringing Arabic let-

\footnotetext{
1 The work was carried out with the financial support of the RFBR (grant № 18-512-76004).
} 
ters (the Arabic alphabet was used in the Ottoman Empire). Turkish typesetters received salaries from the government, while Sopron himself paid the Serbian typesetters. After six months of work, the printing house was bought by the Ottoman authorities for 600 ducats and became known as the Vilayet Printing House. Its staff included a director, two typesetters, four assistants, a translator and a newspaper boy.

Local authorities gave Sopron permission to publish their non-governmental newspaper. Thus, on 7 April 1866 the first Bosnian periodical called Bosanski vjestnik ("The Bosnian Herald") was published. It was printed weekly on Thursdays, and then on Saturdays until April 1867. A total of 52 issues were published. The first issue began with a poem dedicated to Osman Pasha. The materials were published in "vykovitsa" (Serbian) Cyrillic alphabet, developed at the beginning of the 19th century for the Serbo-Croatian language by Vuk Karadzhich based on the Herzegovina dialect. Each issue had eight pages and the following sections: local and foreign news, trade news, interesting facts, news, announcements. The newspaper also published the vilayet's laws, which the local population could read in their native language for the first time. Translations from Turkish were made by a teacher of the Serbian school from Priyepolye, Milosh Mandich (1843-1900). Under the pseudonym hieromonk Theophile Petranovich, the teacher of the Sarayevo school, Bogolyub Petranovich, published folk songs of Bosnia and Herzegovina. The clerk and muwaqqit (a person charged with the regulation and maintenance of the clocks and with communicating the correct times of prayer to the muezzin) of the Gazi Khusrev-beg mosque in Sarayevo, Salikh Sidki Hadzhihuseinovich (1825-88), also collaborated with the publication. In the pages of "The Bosnian Herald," he began to publish his work on Ottoman managers in Bosnia.

"The Bosnian Herald" and Sopron himself criticized the Serbs of the Principality and the Croats. The Serbs were dissatisfied with the use of the term "the Bosnian language" on the pages of the newspaper, and the Croats did not like its use of the Cyrillic alphabet. Both of them accused the typographer of Turkophilism. The question of the re-

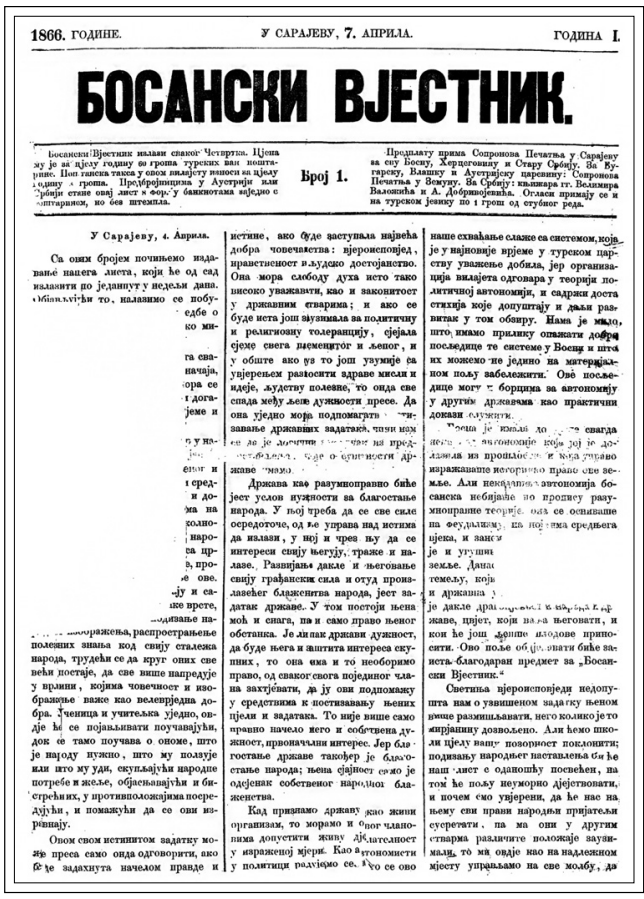

First Bosnian newspaper, "The Bosnian Herald"

(1866-67) 
lationship of Sopron with the Ottoman authorities remains unclear. In April 1866 he returned to Zemun, but after that he continued to issue a newspaper for some time.

Quite quickly a second newspaper appeared in Bosnia. The following news was reported in Issue No. 4 of the "Bosnian Herald" in 1866: "The long-awaited type slugs with Turkish letters arrived in Brchko from Constantinople together with the Turkish typesetter, Kadri Effendi, and as soon as some more things are delivered from Orshova (a city in Romania. $-K . M$.), the release of the official newspaper, Bosna, will be launched in the Turkish and Bosnian languages, the release of which is eagerly awaited throughout the vilayet; there are already more than 1000 subscribers."

The official vilayet newspaper Bosna ("Bosnia") was published in May 1866; just 40 days after the "The Bosnian Herald." The Russian consul in Sarayevo, Eugraph Romanovich Shchulepnikov (1858-68), wrote on this occasion to the ambassador in Constantinople, Nikolay Pavlovich Ignatiev: "Last week the first issue of the local official newspaper in Turkish and Serbian called Bosna was published. It was full of praise for the Sultan for setting up a printing house here and contained absolutely nothing worthy of attention."

The newspaper was published once a week on four pages and was bilingual, printed in the Ottoman and Bosnian (Serbian Cyrillic) languages. The publication covered the news of the vilayet and the Ottoman Empire, as well as foreign news, texts of laws and their explanations. The chief editors at different times were Sarailiya Mustafa Refet-Imamovich (1866-68), Mehmed Shachir Kurtchekhaich (1868-72) and Salikh Biogradliya (1872-78). The main sources of information were newspapers published in Constantinople. The translation of articles and reports from the Ottoman language was carried out by the aforementioned Milosh Mandich. In just 13 years, 636 issues were released. In the final one, dated 18 July 1878, it was reported that the Austro-Hungarian consulate in Sarayevo had announced the readiness of the army of the Habsburg monarchy to move to Bosnia and Herzegovina, which occurred on 29 July.

From December 1868 to 1872 on Thursdays, then on Saturdays, the weekly literary and political edition of the Sarajevski Cvjetnik ("The Sarayevo Flower Garden") was published, which was also bilingual (a total of 170 issues). The first issues of the newspaper were printed on yellow paper; therefore, the name "yellow newspaper" took hold.

The editor-in-chief was the director of the Vilayet Printing House and the official translator from Turkish, Mehmed Shachir Kurtchekhaich. He was also the main author of articles. The newspaper aimed to support all the undertakings and policies of the Ottoman authorities. In his notes, Kurtchekhaich actively polemicized with Serbian (Vidovdan / "The Day of St Vitus"; Mlada Srbija / "The Young Serbia"; Glas naroda / "The Voice of the People"; Yedinstvo / "The Unity") and Montenegrin newspaper Crnogorac / "The Montenegro", as well as with publications of the Slavs of Austria-Hungary (Zastava, Panchevac, Narodni list, 
Pozor, etc.). In the pages of "The Sarayevo Flower Garden," much was written about Serbian expansionist plans toward Bosnia, and it was therefore banned in the Principality of Serbia.

The main task of the newspaper was to educate the people, to combat ignorance and superstition. In addition to domestic and foreign news, a permanent column appeared with medical advice led by a military doctor from Sarayevo Veli-beg (Hungarian Bechliya Gall). In his articles, he talked about the basics of first aid in emergency cases, about the need to follow a diet after childbirth, medicines recommended to be taken in the spring, and he also provided details about diseases such as syphilis, measles and tonsillitis. "The Sarayevo Flower Garden" also paid great attention to the problems of developing agriculture and trade. It gave advice on raising livestock and sowing fields, reported on the last major trading operations in the vilayet.

The release of "The Sarayevo Flower Garden" ceased after the death of editor-in-chief Mehmed Shachir Kurtchekhaich in 1872. He is still considered one of the most important journalists in the history of Bosnia.

After the separation of Herzegovina from the Bosnian vilayet in 1876, part of the equipment of the Vilayet Printing House was moved to the city of Mostar. Here they began to issue an official weekly newspaper, "The Neretva." It too was bilingual. Allegedly, about 40 issues were released, of which only four survived. The editor-in-chief was Mehmed Hulusi (1843-1907). Local and foreign news were published in the pages of the publication, and a lot of attention was paid to education. In its structure, "The Neretva" resembled the "Bosnia" newspaper.

The editorial staff actively collaborated with representatives of all faiths. Their freelance correspondents, in particular, were the Metropolitan of the DabroBosnian diocese, Dionysius II, and the Sarayevo Archimandrite Sava Kosanovich. The main idea of Osman Pasha was to make Bosnian newspapers interesting and accessible to all residents of the vilayet, who were called Bosniaks in the pages of periodicals, and their native language was Bosnian. It can be noted that the quality of the materials left much to be desired. They published a lot of funny, curious messages. Local residents could already learn foreign news and exchange rates by subscribing to Serbian and Austrian newspapers, but finally they had the opportunity to get acquainted with the news and laws of their own vilayet. From 1867 onward the Bosnian authorities banned the import and distribution of Slavic newspapers from Austria-Hungary and Serbia. Thus, the vilayet periodicals became the only available sources of information for the Bosnians. After the occupation of Bosnia and Herzegovina by Austria-Hungary, many employees of Bosnian newspapers began to work in the editorial offices of the periodicals of the Habsburg monarchy. 


\section{BIBLIOGRAPHY}

Ademović F. Prve novine i prvi novinari u Bosni i Hercegovini. Sarajevo, 1999.

Babić B., Janić J. Sopronova pechatnya. Banja Luka, 2016.

Dizdar S. Bibliografija sarajevskog cvjetnika: prilog povijesti knjige. Sarajevo, 2017.

Dizdar S. Prvi Bošnjački novinar: Mehmed Šaćir Kurtćehajić (1844-72) // Bosniaca.

Časopis Nacionalne i univerzitetske biblioteke Bosne i Hercegovine. God 17. Br. 17.

(decembar 2012). S. 60-67

Koetschet J. Osman Pascha, der letzte grosse Wesier Bosniens und seine Nachfolger.

Sarajevo, 1909.

Kruševac T. Bosansko-hercegovački listovi u XIX veku. Sarajevo, 1978.

Pejanović Đ. Štampa Bosne i Hercegovine 1850-1941. Sarajevo, 1949.

\section{ILLUSTRATIONS}

1. The governor of Bosnian vilayet Topal Sherif Osman Pasha (1861-69).

2. The first Bosnian newspaper, "The Bosnian Herald" (1866-67).

3. The second Bosnian newspaper "Bosnia," which began to appear in 1866.

4. The Russian consul in Sarayevo Eugraph Romanovich Shchulepnikov (1858-68).

5. The Russian ambassador to Constantinople, Nikolay Pavlovich Ignatiev.

6. The editor of the newspaper "Bosnia" Mehmed Shachir Kurtchekhaich (1868-72).

7. The Bosnian weekly "The Sarayevo Flower Garden" (1868-72).

8. The Bosnian weekly "The Neretva," published since 1876 in Mostar.

9. Sarayevo Archimandrite Sava Kosanovich. 